\title{
Stability-Indicating Micelle-Enhanced Spectrofluorimetric Method for Determination of Tamsulosin Hydrochloride in Dosage Forms.
}

\author{
Mohamed. Rizk ${ }^{\mathrm{a}}$, Safaa S.Toubar ${ }^{\mathrm{a}}$, Ibrahim H.I. Habib ${ }^{\mathrm{b}}$, Mona S. Elshahed ${ }^{\mathrm{a} \star}$ \\ ${ }^{a}$ Department of Analytical Chemistry, Faculty of Pharmacy, University of Helwan, Egypt \\ b- Analytical Chem. Lab, Applied Organic Chem. Dept., National Research Centre, Dokki, Cairo, Egypt
}

\begin{abstract}
:
A rapid, simple and highly sensitive spectrofluorimetric method is developed for the determination of Tamsulosin hydrochloride (Tams. $\mathrm{HCl}$ ) in phamaceutical formulations. The proposed method is based on investigation of the fluorescence spectral behavior of Tams. $\mathrm{HCl}$ in a sodium dodecyl sulphate (SDS) micellar system. In aqueous solution of Tris buffer of pH $7 \pm 0.2$, SDS causes marked enhancement in the fluorescence intensity of Tams. $\mathrm{HCl}$ (about $+110 \%$ ). The fluorescence intensity is measured at $328 \mathrm{~nm}$ after excitation at $280 \mathrm{~nm}$ and the fluorescence-concentration plots are rectilinear over the range 0.1-1.2 $\mathrm{g} \mathrm{ml}^{-1}$, with lower detection limit of $0.027 \mathrm{\mu g} \mathrm{ml}^{-1}$ and quantification limit of $0.09 \mu \mathrm{g} \mathrm{m} r^{-1}$. The method is successfully applied to the analys is of the studied drug in its commercial capsules, and the results are in good agreement with those obtained with the official method. The application of the proposed method is extended to stability studies of Tamsulosin hydrochloride after exposure to different forced degradation conditions, such as acidic, alkaline and oxidative conditions, according to $\mathrm{ICH}$ guidelines.
\end{abstract}

Keywords: Tamsulosin hydrochloride, sodium dodecyl sulphate, micellar system

\section{Council for Innovative Research}

Peer Review Research Publishing System

\section{Journal: Journal of Advances in Chemistry}

Vol. 11, No. 2

editorjaconline@gmail.com 


\section{INTRODUCTION:}

Tamsulos in 5-[(2R)-2-[[2-(2-Ethoxyphenoxy)eth yl]amino]propyl]-2- ethoxybenzene-sulfonamide [1] (Fig. 1). Tamsulosin is an alpha1-adrenoceptor blocker; it is reported to be more selective for the alpha $1 \mathrm{~A}$-adrenoceptor subtype. It is used in benign prostatic hyperplasia to relief symptoms of urinary obstruction. Tamsulosin is given by mouth as the hydrochloride salt in a modified-release formulation, in a dose of $400 \mu \mathrm{g}$ once daily [2]. Several analytical procedures describing the detemination of Tamsulosin have been published; these methods include non-aqueous titration [3], voltammetry [4] and spectrophotometry [5]. Several chromatographic methods were described for determination of Tamsulosin, such as highperformance liquid chromatography (HPLC) with UV detection [3, 6-9], fluorescence detection [10], mass spectrometric detection [11-15], and capillary electrophoresis [16].

The key characteristic of fluorescence spectrometry is its high sensitivity. Fluorometry may achieve limits of detection several orders of magnitude lower than those of most other techniques. Because of the low detection limits, fluorescence is widely used for quantification of trace constituents of biological and environmental samples. Most complex samples contain one or more components that can quench the fluorescence of the analyte. Thus, it often is necessary to subject complex samples to be analyzed by fluorometry to extensive prior cleanup to remove potential quenchers. Alternatively, one may try to provide a uniform microenvironment for the analyte and thus a reproducible fluorescence yield from sample to sample by adding a micelle forming surfactant to each sample [17]. This is based on the fact that fluorescent molecules in solution may be partially or fully hidden from quenchers by incorporating them into organized media such as surfactant micelles or cyclodextrin cavities [18]. The environment seen by a micelle-solubilized solute differs from that encountered in aqueous solution in having a higher local viscosity which decreases collision-induced non-radiative decay or possible quenching reactions, resulting in increased fluorescence quantum yield with a subsequent increase in analytical sensitivity [19]. Recently, micelle-enhanced fluorescence using sodium dodecyl sulfate (SDS) has been utilized for the spectrofluorometric detemination of Ezetimibe [20], loratadine and desloratadine [21], galantamine [22], verapamil hydrochloride [23], gatifloxacin [24], garenoxacin in human urine and serum [25], naproxen [26], Levofloxacin [27], ellipticine [28], carbendazim [29] and fenproporex [30]. Surveying the literature revealed that there is no reported spectrofluorometric method for the determination of Tams. $\mathrm{HCl}$ using organized media. Tams. $\mathrm{HCl}$ is considered as a minor phamaceutical active ingredient which needs highly sensitive methods to be detemined in its dosage forms and biological fluids. The objective of the present work is to study the effect of SDS micellar medium on enhancing the native luminescence characters of Tams. $\mathrm{HCl}$ in order to develop a new simple and sensitive micro analytical methodology for determination of the studied drug in its dosage forms.

\section{EXPERIMENTAL:}

\section{Apparatus}

All the fluorescence spectra were recorded using a JASCO FP-6200 Spectrofluorometer, equipped with 150 W Xenon lamp, grating excitation and emission monochromators, and a recorder. Slit widths for both monochromators were set at $10 \mathrm{~nm}$; they were set at $5 \mathrm{~nm}$ for fluorescence quantum yield measurements. A $1 \mathrm{~cm}$ quartz cell was used. Spectra were evaluated using Spectra Manager FP-6200 Control Driver software, Version 1.54.03 [Build 1], JASCO Corporation.

\section{Materials and reagents}

\section{a) Pure materials:}

- Tams. $\mathrm{HCl}$, was purchased from SIGMA pharmaceutical industries (Osmopham , Swittazerland), its percent purity was $100.68 \%$ as received.

\section{b) Pharmaceutical preparations:}

-Tamsulin capsules Manufactured by (Marcyrl Pharmaceutical industries, Elobour City, Egypt), were purchased from commercial sources in the local market. Each capsule is labeled to contain $0.4 \mathrm{mg}$ of Tamsulosin $\mathrm{HCl}$. Batch Number1020774

-Tamic capsules Manufactured by (Sigma Pharmaceutical industries, Egypt), were purchased from commercial sources in the local market. Each capsule is labeled to contain $0.4 \mathrm{mg}$ of Tamsulosin HCl. Batch Number 81774 .

\section{c) Reagents:}

All chemicals used were of analytical reagent grade and were used without further purification.

$>$ SDS (Rediel-De- Haen, Gemany), $1.0 \%$ (W/V) aqueous solution was prepared by dissolving $10 \mathrm{~g}$ SDS in distilled water, and then it was diluted to $1 \mathrm{~L}$ with the same solvent. It is stable for 7 days when left in the refrigerator.

$>$ B-cyclodextrin was obtained from Merck (Germany), $0.05 \%$ (W/V) aqueous solution was prepared by dissolving $0.5 \mathrm{~g}$ B-cyclodextrin in distilled water, and then it was diluted to $100 \mathrm{ml}$ with the same solvent.

$>$ Tris-Chloride buffer [Tris (hydroxyl methyl) amino methane] was obtained from (Fluka Bio Chemika), $0.1 \mathrm{M}$ aqueous solution $\mathrm{pH} 7 \pm 0.2$ was prepared according to the B.P. 
$>$ Mcllvaine buffer[31], $\mathrm{pH}$ ( 2.2-7) was prepared by mixing appropriate volumes of $0.1 \mathrm{M}$ citric acid and $0.2 \mathrm{M}$ disodium hydrogen orthophosphate, both citric acid and disodium hydrogen orthophosphate were obtained from El-Nasr Pharmaceutical Chemical Co. (ADWIC; Egypt).

$>$ Methanol HPLC grade $99.9 \%$ (Sigma, Germany)

$>$ Hydrochloric acid HPLC grade 37 \% (Rediel -De- Haen, Germany) , 2.0 Maqueous solution was prepared.

$>$ Sodium chloride (Winlab, Leicestershire, U.K.)

$>$ Sodium hydroxide pellets (Winlab, Leicestershire, U.K.) $2.0 \mathrm{M}$ aqueous solution was prepared.

\section{Standard solutions}

\section{Tams. HCl Stock solutions:}

Stock solution $1\left(250.0 \mathrm{\mu g} \mathrm{ml}^{-1}\right)$ was prepared by dissolving $25.0 \mathrm{mg}$ of Tams. $\mathrm{HCl}$ in $100.0 \mathrm{ml}$ of methanol.

Stock solution $2\left(20.0 \mu \mathrm{g} \mathrm{ml}^{-1}\right)$ was prepared by diluting $8.0 \mathrm{ml}$ of Stock solution 1 to $100.0 \mathrm{ml}$ with distilled water.

\section{Tams. $\mathrm{HCl}$ working solution:}

A working solution $\left(4 \mathrm{\mu g} \mathrm{ml}^{-1}\right)$ was prepared by diluting $20.0 \mathrm{ml}$ of Stock solution 2 to $100.0 \mathrm{ml}$ with distilled water.

\section{General procedures}

\section{a) Procedure for calibration graph.}

Aliquots from Tams. $\mathrm{HCl}$ working solution equivalent to $(1.0-12.0 \mu \mathrm{g})$ Tams. $\mathrm{HCl}$ were transferred into a series of $10-\mathrm{ml}$ volumetric flasks. Then $2.0 \mathrm{ml} 0.1 \mathrm{M}$ Tris-Chloride buffer solution, $\mathrm{pH} 7 \pm 0.2$, were added to each flask, followed by $2.0 \mathrm{ml}$ $1.0 \% \mathrm{w} / \mathrm{v}$ SDS solution. The volume was completed with distilled water; the contents of the flasks were mixed well. A blank experiment was performed simultaneously and the relative fluorescence intensity was measured at $328 \mathrm{~nm}$ after excitation at $280 \mathrm{~nm}$. The corrected fluorescence intensities were plotted against the final drug concentrations $\left(\mu \mathrm{g} \mathrm{ml^{-1 }}\right)$ to obtain the calibration graph. Alternatively, the corresponding regression equation was derived.

\section{b) Procedure for capsules.}

The contents of not fewer than ten capsules were weighed and mixed well. An amount of the capsule pellets equivalent to $1 \mathrm{mg}$ Tams. $\mathrm{HCl}$ was accurately weighed, transferred to $25-\mathrm{ml}$ volumetric flask and dissolved in methanol. The flask was sonicated for 30 minutes then, completed to volume with the same solvent. The produced solution $\left(40 \mu \mathrm{g} \mathrm{ml}{ }^{-1}\right)$ was used to prepare aqueous working solution $\left(4 \mathrm{\mu g} \mathrm{m}^{-1}\right)$. Aliquots from working solution covering the concentration range cited in table (1) were transferred into a series of $10-\mathrm{ml}$ volumetric flasks, the 'Procedure for calibration graph' (above) was then perfomed. The capsule content was determined either from a previously plotted calibration graph or using corresponding regression equation.

\section{c) Procedure for biological fluids.}

Aliquots of human plasma equivalent to $1.0 \mathrm{ml}$ were transferred into centrifugation tubes and spiked with $1.0 \mathrm{ml}$ of Tams. $\mathrm{HCl}$. Then, $2.0 \mathrm{ml}$ acetonitril were added to each tube. The mixture was centrifuged at $6000 \mathrm{~mm}$ for $20 \mathrm{minutes} .1 .0$ $\mathrm{ml}$ of the supernatant was carefully transferred to a measuring flask and the 'Procedure for calibration graph' was then applied. A blank experiment was carried out simultaneously. The drug content in plasma was determined using corresponding regression equation.

\section{d) Procedures for stability indicating assay}

\section{- Alkaline and acidic degradation.}

Aliquots of Tams. $\mathrm{HCl}$ Stock solution 1 (equivalent to $250.0 \mu \mathrm{g}$ of the drug) were transferred into a series of small conical flasks; aliquots of $2 \mathrm{M} \mathrm{NaOH}$ or $2 \mathrm{M} \mathrm{HCl}$ equivalent to $5.0 \mathrm{ml}$ were added. The flasks were heated in a boiling water bath for different time intervals $(5-60 \mathrm{~min})$. At the specified time intervals, the contents of each flask were cooled and neutralized to $\mathrm{pH} 7.0$ with $2 \mathrm{M} \mathrm{HCl}$ or $2 \mathrm{M} \mathrm{NaOH}$, respectively. The solutions were then transferred into 25 -ml volumetric flasks and completed to volume with water. One $\mathrm{ml}$ of the resulting solutions was then transferred into 10-ml volumetric flasks and the procedure 'Procedure for calibration graph' was performed.

\section{- Oxidative degradation.}

Aliquots of Tams. $\mathrm{HCl}$ Stock solution 1 (equivalent to $250.0 \mu \mathrm{g}$ of the drug) were transferred into a series of $25-\mathrm{ml}$ volumetric flasks; different volumes of $10 \% \mathrm{H}_{2} \mathrm{O}_{2}$ were added and the volume was completed with water. One $\mathrm{ml}$ of these solutions was transferred into 10-mI volumetric flasks and the procedure 'Procedure for calibration graph' was perfomed.

\section{- Photo-degradation.}

Aliquots of Tams. $\mathrm{HCl}$ Stock solution 1 (containing $250.0 \mu \mathrm{g}$ of the drug) were transferred into $25-\mathrm{mL}$ volumetric flasks and completed to volume with distilled water. The volumetric flasks were exposed to UV light at a wavelength of $254 \mathrm{~nm}$ and at 
a distance of $15 \mathrm{~cm}$, placed in a wooden cabinet, for 5 hours. one $\mathrm{ml}$ of the solutions was then transferred into 10-ml volumetric flasks and the procedure 'Procedure for calibration graph' was performed.

\section{RESULTS AND DISCUSSION}

Tams. $\mathrm{HCl}$ was found to exhibit a weak emission band at $328 \mathrm{~nm}$ in aqueous Tris -Chloride buffer solution of $\mathrm{pH} 7$ after excitation at $280 \mathrm{~nm}$. This work aimed to enhance this emission band, in order to develop a new methodolo gy for the analysis of Tams. $\mathrm{HCl}$ in its phamaceutical preparations. The use of different types of surfactants to enhance the fluorescence of many drugs has found wide applications in the field of analysis. When a surfactant at a concentration above its critical micellar concentration is added to a given fluorophore solution, it increases the molar absorbtivity and/or the fluorescence quantum yield of the fluorophore in many cases [32]. This fact has been used to improve the performance of spectrofluorimetric methods of various analytes. The fluorescence properties of Tams. $\mathrm{HCl}$ were studied in different types of organized media (SDS, $\beta$ - cyclodextrin and Tween 80). Tween 80 caused severe decrease in the RFI of the studied drug while the addition of SDS caused an enhancement (about 110\%) of its fluorescence intensity compared with aqueous solution (Fig. 2). On the other hand $\beta$-cyclodextrin showed no marked effect on the fluorescence intensity of Tams. $\mathrm{HCl}$ (Fig. 3), therefore SDS was used as a fluorescence enhancer in order to develop a new spectrofluorimetric method for the determination of Tams. $\mathrm{HCl}$ in its dosage form.

\section{Optimization of the reaction conditions}

\section{a) Effect of $\mathrm{pH}$ and type of buffer}

The influence of $\mathrm{pH}$ on the micelle enhanced fluorescence of Tams. $\mathrm{HCl}$ was studied using different types of buffers covering wide $\mathrm{pH}$ range, such as Mcllvaine buffer over the $\mathrm{pH}$ range 3-7 and $0.1 \mathrm{M}$ Tris-Chloride buffer over the $\mathrm{pH}$ range 7-10. It was found that maximum RFI was achieved over the $\mathrm{pH}$ range $4.0-8.0$; increasing the $\mathrm{pH}$ value above $\mathrm{pH} 8.0$ caused gradual decreases in the RFI (Fig. 4). Therefore, $\mathrm{pH} 7$ was chosen as the optimum pH value for measurement of $\mathrm{RFI}$ of the studied drug in SDS medium. Comparis on between the RFI of the studied drug in SDS medium of $\mathrm{pH} 7 \mathrm{was}$ carried out using Mcllvaine and Tris-Chloride buffer. No significant difference between the RFI of the drug in the two buffer media, so Tris-Chloride buffer was us ed to adjust the optimum $\mathrm{pH}$ for the reaction.

The pKa value of Tams. $\mathrm{HCl}$ is reported to be 8.4 (secondary amine) [1]. This may explain the reason for the maximum $\mathrm{RFI}$ observed over the $\mathrm{pH}$ range 4.0-8.0 at which the studied drug is mostly present in the protonated form which interact more strongly with the anionic micelles of SDS than the neutral form. It is also reported that the fluorescence intensity for protonated species is always higher than that for neutral species [33].

\section{b) Effect of the volume of SDS}

The influence of SDS on the RFI of Tams. $\mathrm{HCl}$ was studied using increasing volumes of $1.0 \% \mathrm{w} / \mathrm{v}$ SDS. It was found that increasing volumes of SDS solution resulted in a consequent increase in RFI up to $1.0 \mathrm{ml}$, after which no further increase in RFI was observed (Fig. 5). Therefore, $2 \mathrm{ml} 1.0 \% \mathrm{w} / \mathrm{v}$ SDS solution was chosen as the optimum volume to achieve maximum enhancement in RFI of Tams. HCl.

\section{c) Effect of Molar concentration of Tris buffer}

The effect of Molar concentration of Tris buffer $(\mathrm{pH}=7)$ on the RFI of Tams. $\mathrm{HCl}$ in the presence of SDS was studied. Different Molar concentrations ranging from $0.025 \mathrm{M}$ up to $0.2 \mathrm{M}$ were used (Fig. 6). No significant difference in the RFI of the studied drug was observed upon changing the Molar concentration of buffer, so $0.1 \mathrm{M}$ Tris buffer was used to adjust $\mathrm{pH}$ of the reaction.

\section{d) Effect of time}

The effect of time on the RFI of the studied drug was studied over time intervals ranging from five minutes up to two hours. It was found that enhancement of the fluorescence intensity was immediately developed and remained stable for two hours as shown in (Fig.7).

\section{e) Effect of diluting solvent}

The effect of different diluting solvents on the RFI of Tams. $\mathrm{HCl}$ in the presence of SDS was investigated using water, methanol, n-propanol and acetonitrile. It was found that water was the best solvent for dilution, as it gave the highest RFI and the lowest blank reading, also it is cheap, safe and available solvent. Other solvents showed no marked change in the RFI of Tams. $\mathrm{HCl}$ (Fig. 8).

\section{Validation of the proposed method}

The proposed method was tested for linearity, LOQ, LOD, accuracy, precision and robustness.

\section{a) Linearity}

After optimizing the conditions, evaluation of linearity of the assay method was perfomed by analysing seven concentrations for the studied drug (standard calibration plots). The calibration graph of Tams. $\mathrm{HCl}$ was constructed by

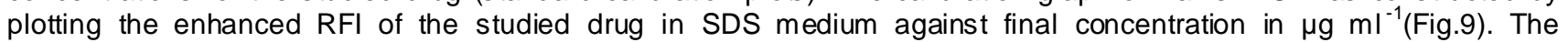


fluorescence - concentration plot was linear over the concentration range $0.10-1.20 \mu \mathrm{g} \mathrm{m}^{-1}$. Analysis of the data gave the following regression equation:

$$
\mathrm{RFI}=829.55 \mathrm{C}-2.150 \quad(r=0.9998)
$$

Where RFI is the relative fluorescence intensity, $C$ is the concentration of the studied drug in $\left(\mu \mathrm{g} \mathrm{ml}{ }^{-1}\right)$ and $(r)$ is the correlation coefficient.

The limit of quantitation ( $L O Q$ ) was determined by establishing the lowest concentration that can be measured according to ICH Q2 (R1) recommendations [34], below which the calibration graph is non-linear. The limit of detection (LOD) was determined by evaluating the lowest concentration of the analyte that can be readily detected.

The values of LOQ and LOD were calculated according to the following equation

$$
\mathrm{LOQ}=10 \mathrm{\sigma} / \mathrm{S} \quad \mathrm{LOD}=3.3 \mathrm{\sigma} / \mathrm{S}
$$

Where $\sigma=$ the residual standard deviation of the regression line

And $S=$ slope of the calibration curve

The results of LOQ and LOD are summarized in Table (1). The proposed method was evaluated by calculating accuracy as percent relative error and precision as percent relative standard deviation, the results are abridged in Table (1). Calibration data of Tams. $\mathrm{HCl}$ in pure form by the proposed method are presented in Table (1).

\section{b) Accuracy and Precision}

The results of the proposed method were compared with those obtained using the official method [3]. Statistical analys is [35] of the results using Student's t-test and Variance ratio F-test revealed no significant difference between the two methods regarding accuracy and precision, respectively Table (2).

\section{c) Repeatability}

The repeatability (intra day precision) was evaluated through replicate analysis of the studied drug in pure form and in Tamsulin capsule using three different concentrations $\left(0.40,0.60\right.$ and $\left.0.80 \mu \mathrm{g} \mathrm{ml}^{-1}\right)$ and each concentration was measured three successive times. The results are summarized in Table (3).

\section{d) Intermediate Precision}

The Intermediate Precision (inter-day precision) was evaluated through replicate analysis of the studied drug in pure form and in Tamsulin capsule on three successive days. The results are abridged in Table (3). The precision of the proposed method was fairly high, as indicated by the low values of SD and \%RSD, respectively. Also the inter-day and intra-day accuracy was proved by the low values of \%Er.

\section{e) Robustness of the method}

The robustness of the proposed method was demonstrated by the constancy of the RFI with minor changes in the experimental conditions, such as the $\mathrm{pH}(7 \pm 0.5)$ and the change in the volume of SDS $(2.0 \pm 0.5 \mathrm{~mL})$. These $\mathrm{minor}$ changes that may take place during the experimental operation did not affect the RFI.

\section{Pharmaceutical application}

The proposed method was applied to the detemination of Tams. $\mathrm{HCl}$ in its commercial dosage foms (Tamsulin capsule, Tamic capsule). Tams. $\mathrm{HCl}$ is official in the USP and so are its capsules. The USP states that Tams. $\mathrm{HCl}$ capsules contain not less than $90.0 \%$ and not more than $110.0 \%$ of the labeled amount. The results obtained by the proposed method were within the USP stated limit and they were compared with those obtained using the reference method [3] Table $(4,5)$. Statistical analysis of the results obtained using Student's t-test and Variance ratio F-test revealed no significant difference between the performance of two methods regarding accuracy and precision, respectively.

\section{Biological application}

The proposed method was applied to the determination of Tams. $\mathrm{HCl}$ in spiked human plasma. The intra-day precision was evaluated through replicate analysis of plasma samples spiked with different concentrations of the studied drug ( 0.4 and $0.8 \mu \mathrm{g} \mathrm{ml}^{-1}$ ). The mean percentage recovery based on the average of five separate determinations of each concentration was 99.51 \pm 5.1. The results are abridged in Table (6).

\section{Results of stability indicating assay}

Tams. $\mathrm{HCl}$ was found to be susceptible to acid degradation after boiling with $2 \mathrm{M} \mathrm{HCl}$ for 1 hour $18 \%$ of the drug was degraded. The studied drug was found to be less susceptible to alkaline degradation as only $7 \%$ of the drug was degraded after boiling with $2 \mathrm{M} \mathrm{NaOH}$ for 1 hour.

Oxidative degradation of Tams. $\mathrm{HCl}$ with hydrogen peroxide was also studied. It was found that treating the drug with $30 \%$ $\mathrm{H}_{2} \mathrm{O}_{2}$ at room temperature, according to the procedure described above, resulted in immediate degradation of Tams. $\mathrm{HCl}$. The amount of the degraded drug was dependent on the volume of $\mathrm{H}_{2} \mathrm{O}_{2}$ added; $84 \%$ degradation was observed upon the addition of $7.0 \mathrm{ml} 30 \% \mathrm{H}_{2} \mathrm{O}_{2}$ to the drug (Fig. 9). 
The effect of $10 \% \mathrm{H}_{2} \mathrm{O}_{2}$ on Tams. $\mathrm{HCl}$ was also studied, as shown in Fig. (10), addition of $6.0 \mathrm{ml} 10 \% \mathrm{H}_{2} \mathrm{O}_{2}$ caused $41 \%$ degradation of the studied drug. The results of stability studies were calculated from fluorescence measurement of Tams. $\mathrm{HCl}$ in both aqueous and micellar media and they were so close in both conditions.

The effect of UV light on the stability of Tams. $\mathrm{HCl}$ was studied by exposing the aqueous drug solutions to the UV light. No considerable degradation was observed upon exposure of the drug to UV light up to 3 hours.

\section{Mechanism of the micellar enhancement effect of SDS on Tams. $\mathrm{HCl}$ fluorescence:}

In order to establish whether the sensitization process of Tams. $\mathrm{HCl}$ fluorescence was only due to an increase in quantum yield, or whether it was affected by an increase in absorption at the excitation wavelength, the molar absorbtivity of Tams. $\mathrm{HCl}$ in the presence of SDS was determined at $280 \mathrm{~nm}$ ( $\lambda$ ex). Table (7) shows that the $\varepsilon$ micellar: $\varepsilon$ water ratio was approximately 1.0, which indicates that the increase in sensitivity is not affected by an increase in the absorption of the studied drug at its $\lambda e x$, but it is due to an increase in the quantum yield of Tams. $\mathrm{HCl}$ by protection of the lowest excited singlet state in the micellar microenvironment from non-radiative processes. The quantum yield of Tams. $\mathrm{HCl}$ was found to be 0.029 in aqueous medium and 0.051 in the presence of SDS as shown in Table (8). The quantum yield was calculated according to the following equation [36]:

$\Phi \mathrm{u}=[\Phi \mathrm{s} F \mathrm{u} / \mathrm{Fs}] \times[\mathrm{As} / \mathrm{Au}]$

where $\Phi u$ and $\Phi$ S referred to the fluorescence quantum yields of the drug and quinine sulphate (Q.S.), respectively; Fu and Fs represented the integral fluorescence intensity of the drug and quinine, respectively; Au and As referred to the absorbance of the drug and quinine at the excitation wavelength, respectively.

\section{CONCLUSION}

The micellar enhanced spectrofluorimetric method proposed for the determination of Tams. $\mathrm{HCl}$, has the advantages of simplicity, speed, accuracy, low detection limit and the use of inexpensive equipment. It can be considered as an attractive alternative to numerous other more complicated methods. The proposed method could be successfully applied for the detemination of the studied drug in pure form and in phamaceutical preparations; the results are in good agreement with the official methods. Moreover, it has been adapted for stability studies of the studied drug as a rapid and simple alternative to the reported stability-indicating HPLC methods.

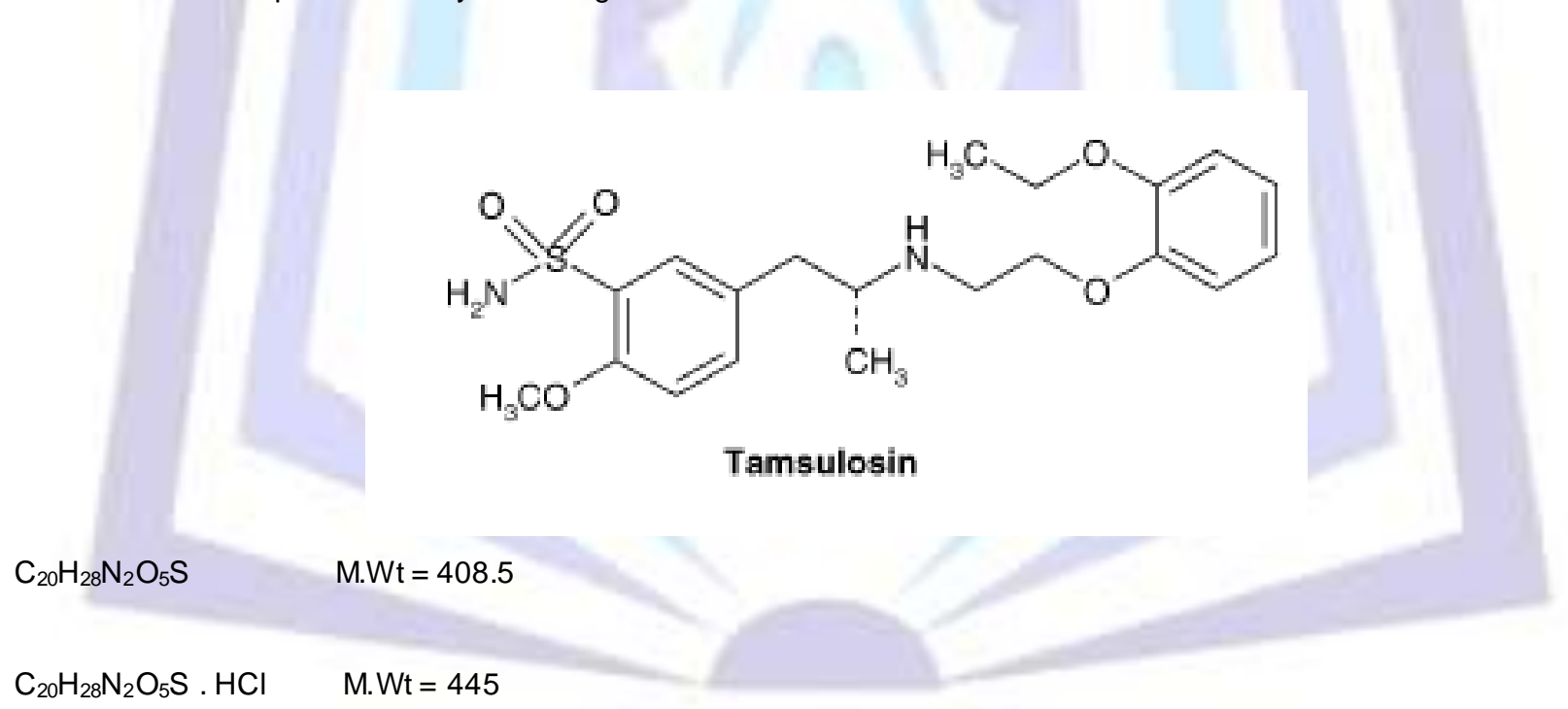

Fig. (1): Tamsulosin Hydrochloride 


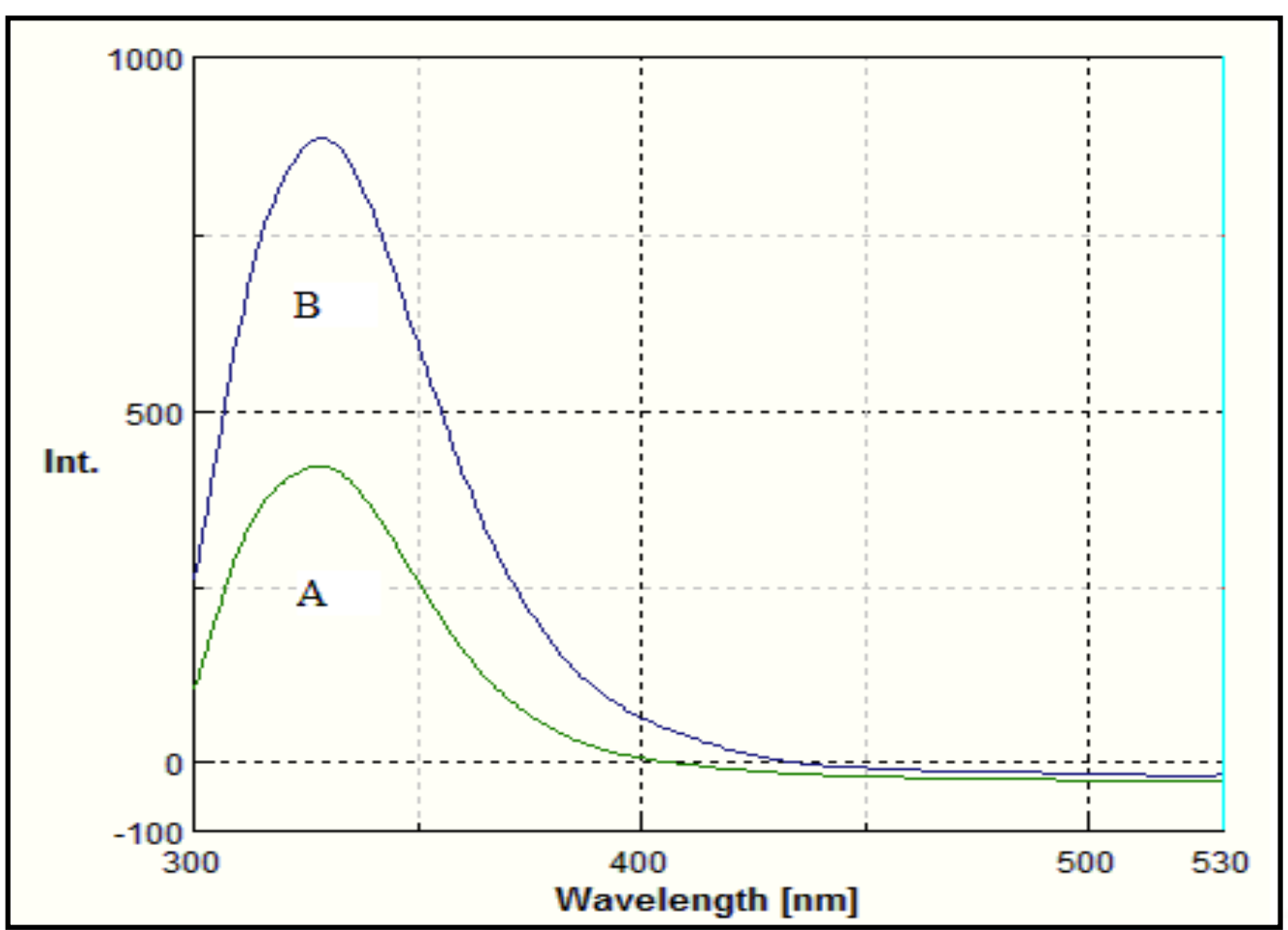

Fig. (2): Emission spectra of Tams. $\mathrm{HCl}\left(1.0 \mu \mathrm{g} \mathrm{m}^{-1}\right)$ in presence of (A) : aqueous Tris buffer of $\mathrm{pH} 7$.

(B) : $1 \%$ SDS medium of $\mathrm{pH} 7$.

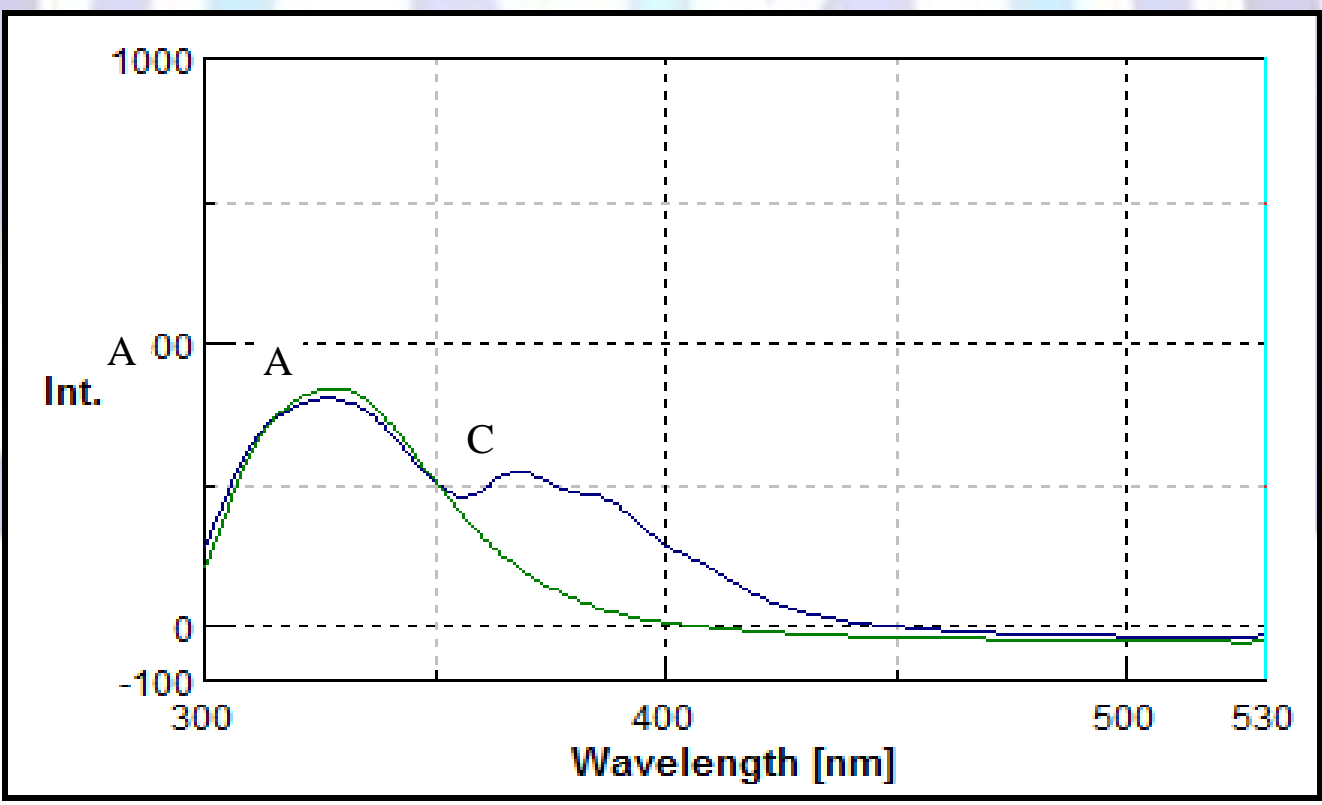

Fig. (3): Emission spectra of Tams. $\mathrm{HCl}\left(1.0 \mu \mathrm{gl}^{-1}\right)$ in presence of

(A) : aqueous Tris buffer of $\mathrm{pH} 7$.

(C) : $0.5 \% \beta$-Cyclodextrine of $\mathrm{pH} 7$. 


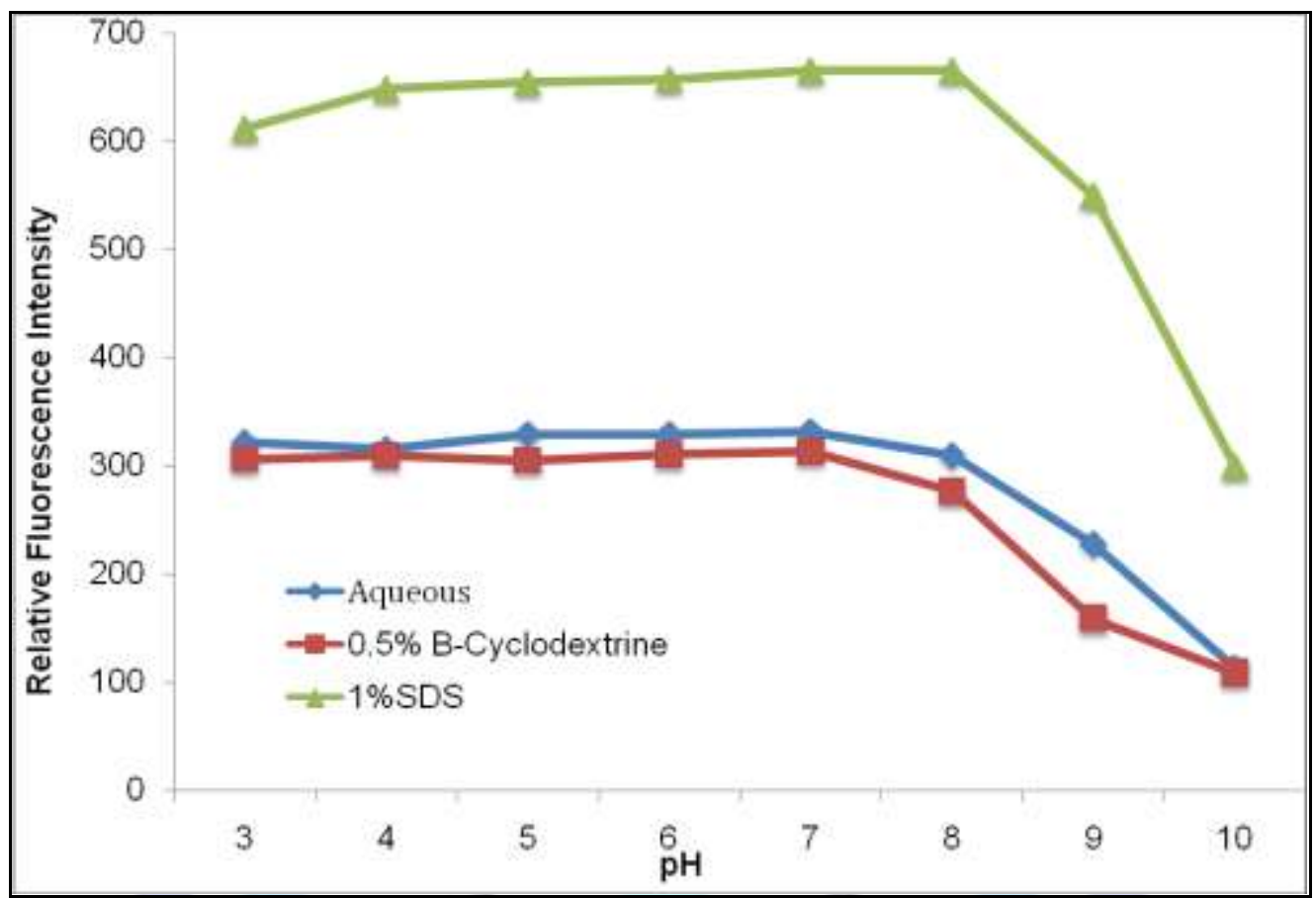

Fig. (4): Effect of $\mathrm{pH}$ on the fluorescence intensity of Tams. $\mathrm{HCl}\left(0.8 \mu \mathrm{g} \mathrm{m}^{-1}\right)$ in presence of : Aqueous , $=0.5 \% \beta$ - Cyclodextrine and $\triangle 1 \%$ SDS media.

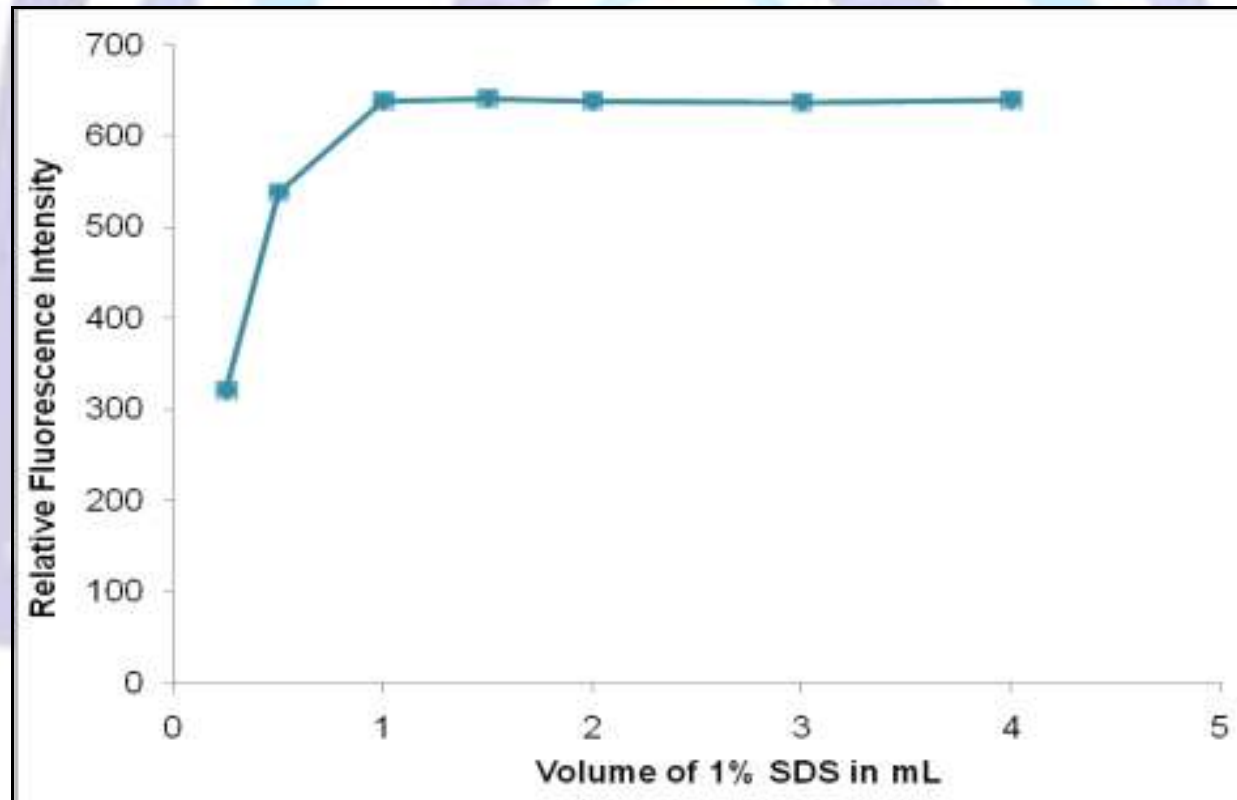

Fig. (5): Effect of volume of $1 \%$ SDS solution on the relative fluorescence intensity of Tams. $\mathrm{HCl}$ $\left(0.8 \mu \mathrm{gll}^{-1}\right)$. 


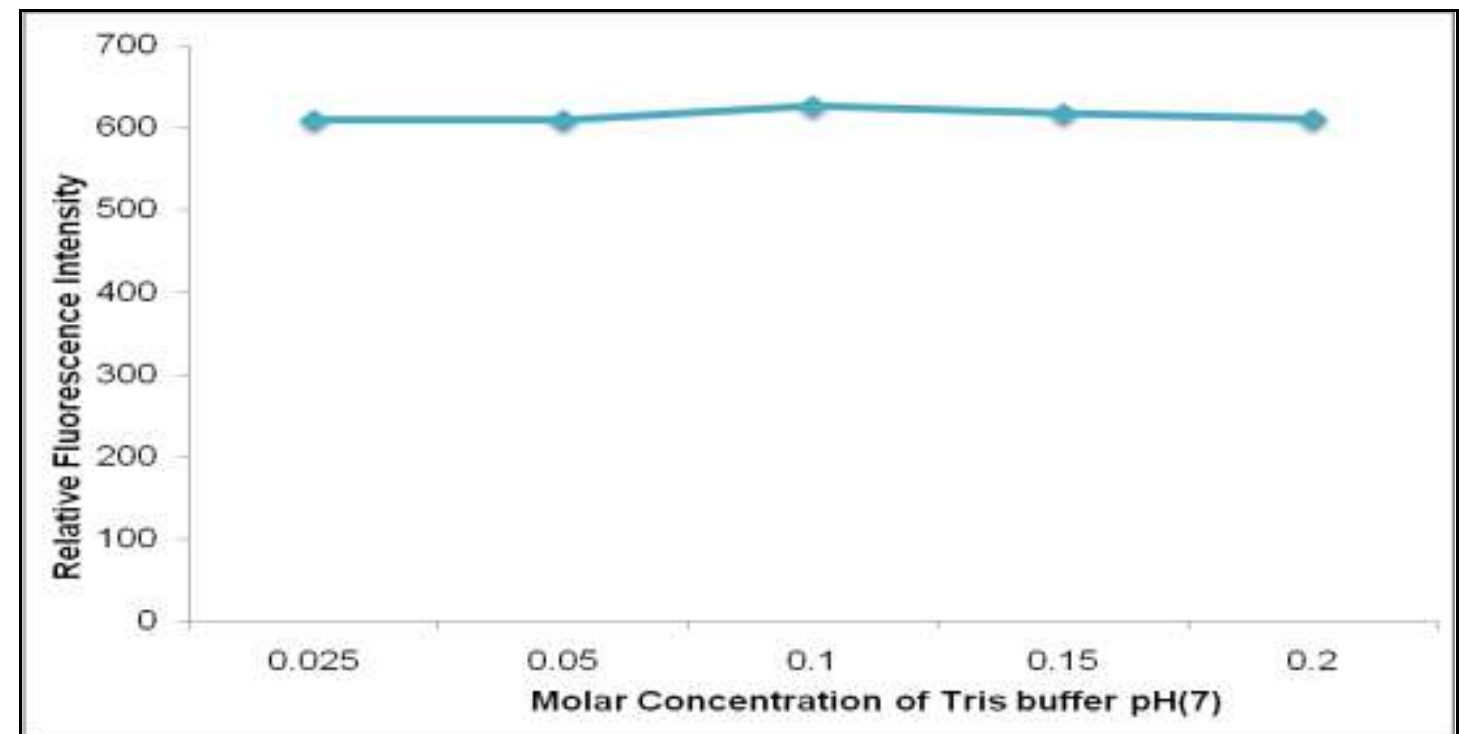

Fig. (6): Effect of Molar concentration of Tris buffer $(\mathrm{pH}=7)$ on the relative fluorescence intensity of Tams. $\mathrm{HCl}$ $\left(0.8 \mu \mathrm{g} \mathrm{ml}^{-1}\right)$.

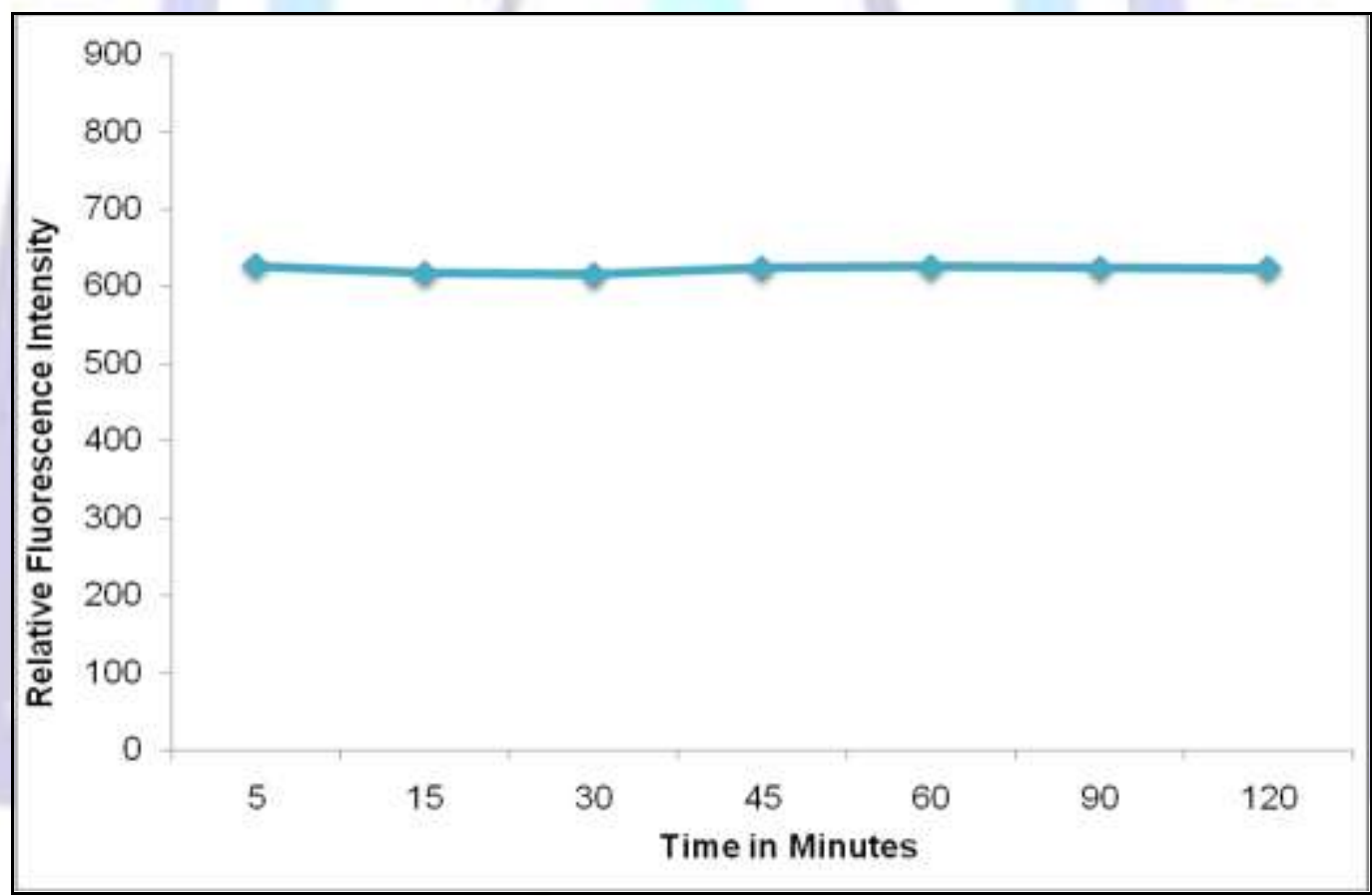

Fig. (7): Effect of time on the relative fluorescence intensity of Tams. $\mathrm{HCl}\left(0.8 \mu \mathrm{ml}^{-1}\right)$. 


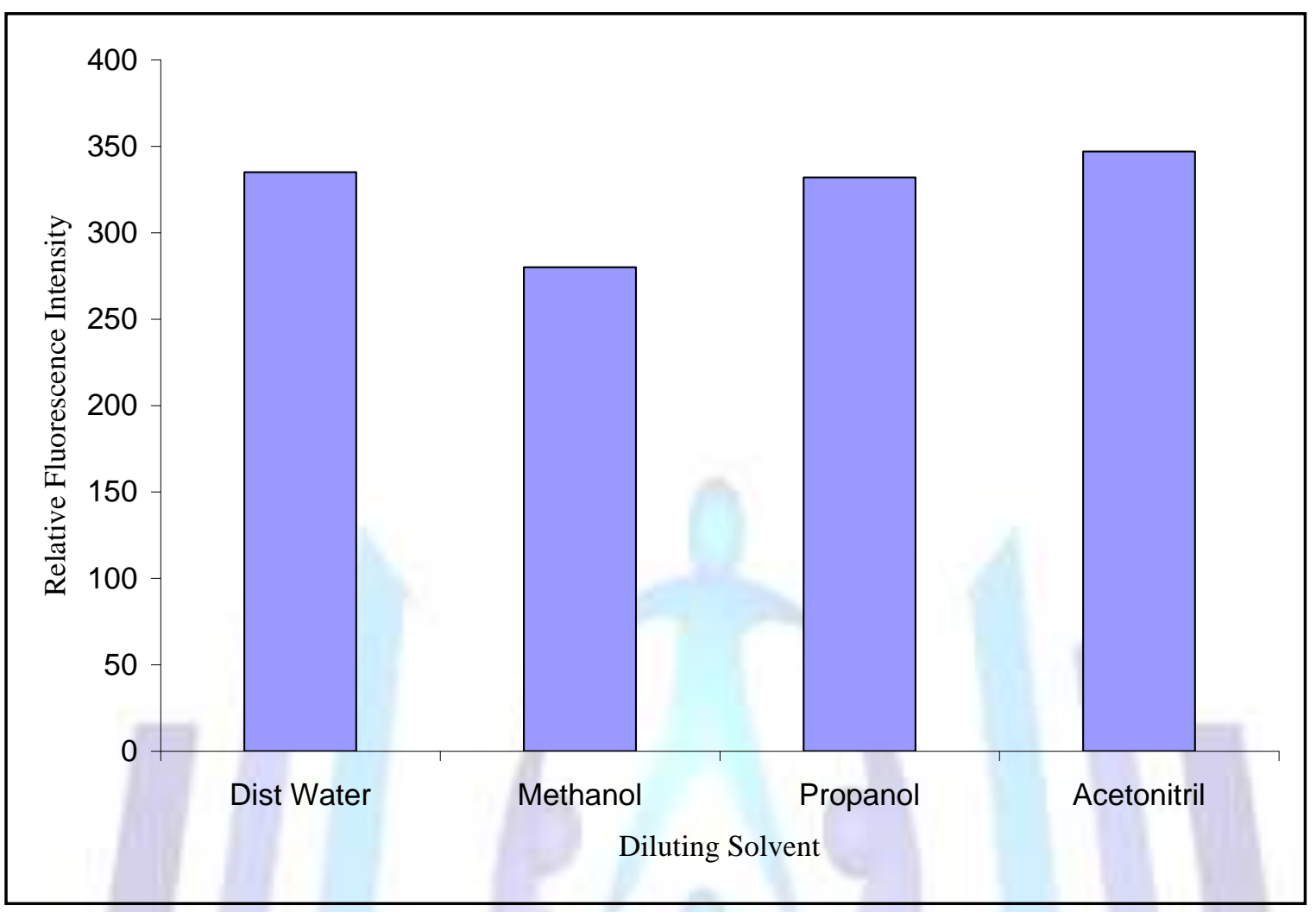

Fig. (8): Effect of diluting solvent on the relative fluorescence intensity of Tams. $\mathrm{HCl}\left(0.4 \mu \mathrm{gl}^{-1}\right)$.

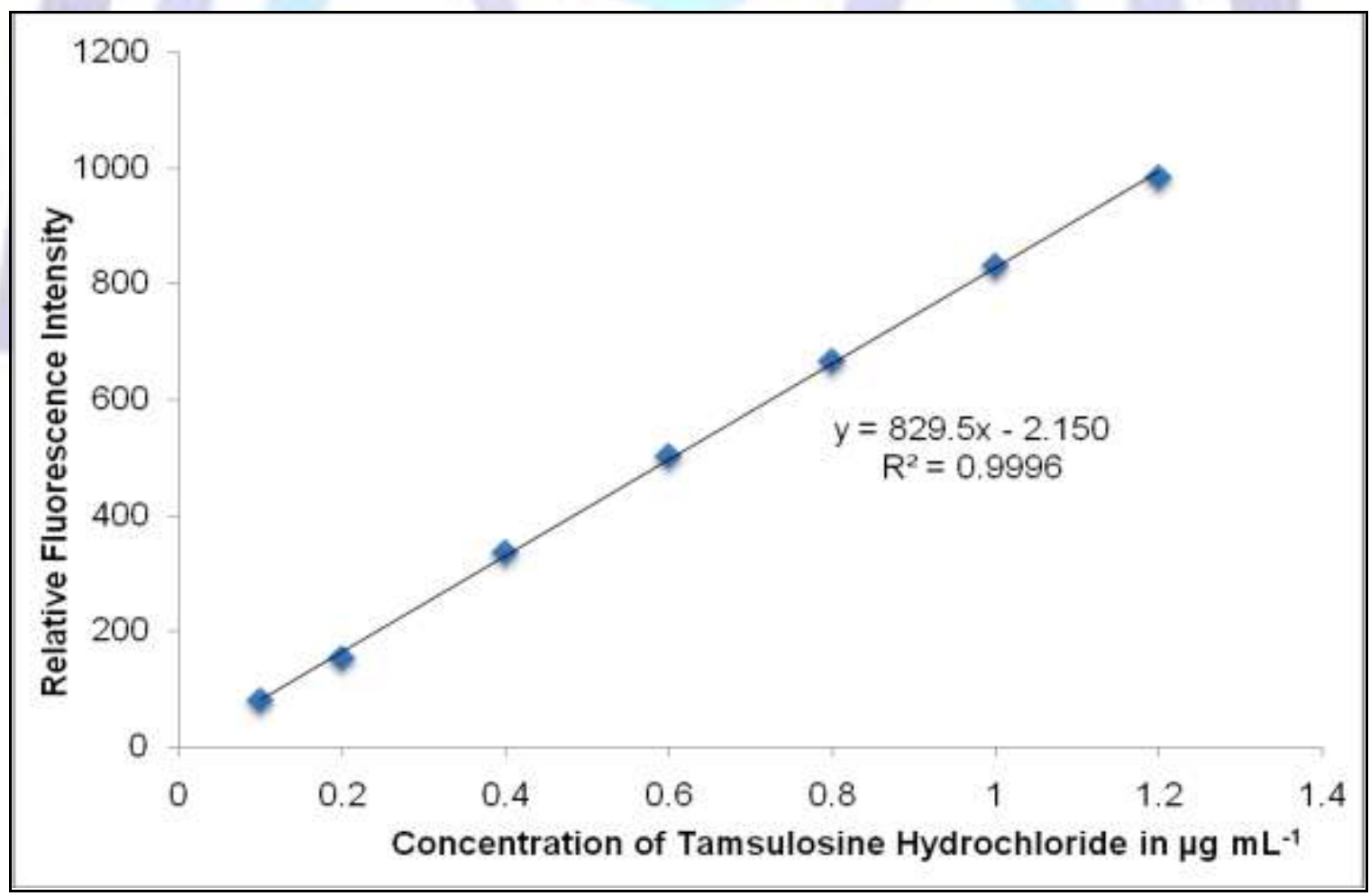

Fig. (9): Calibration graph of Tams. $\mathrm{HCl}$ in pure form using SDS system 


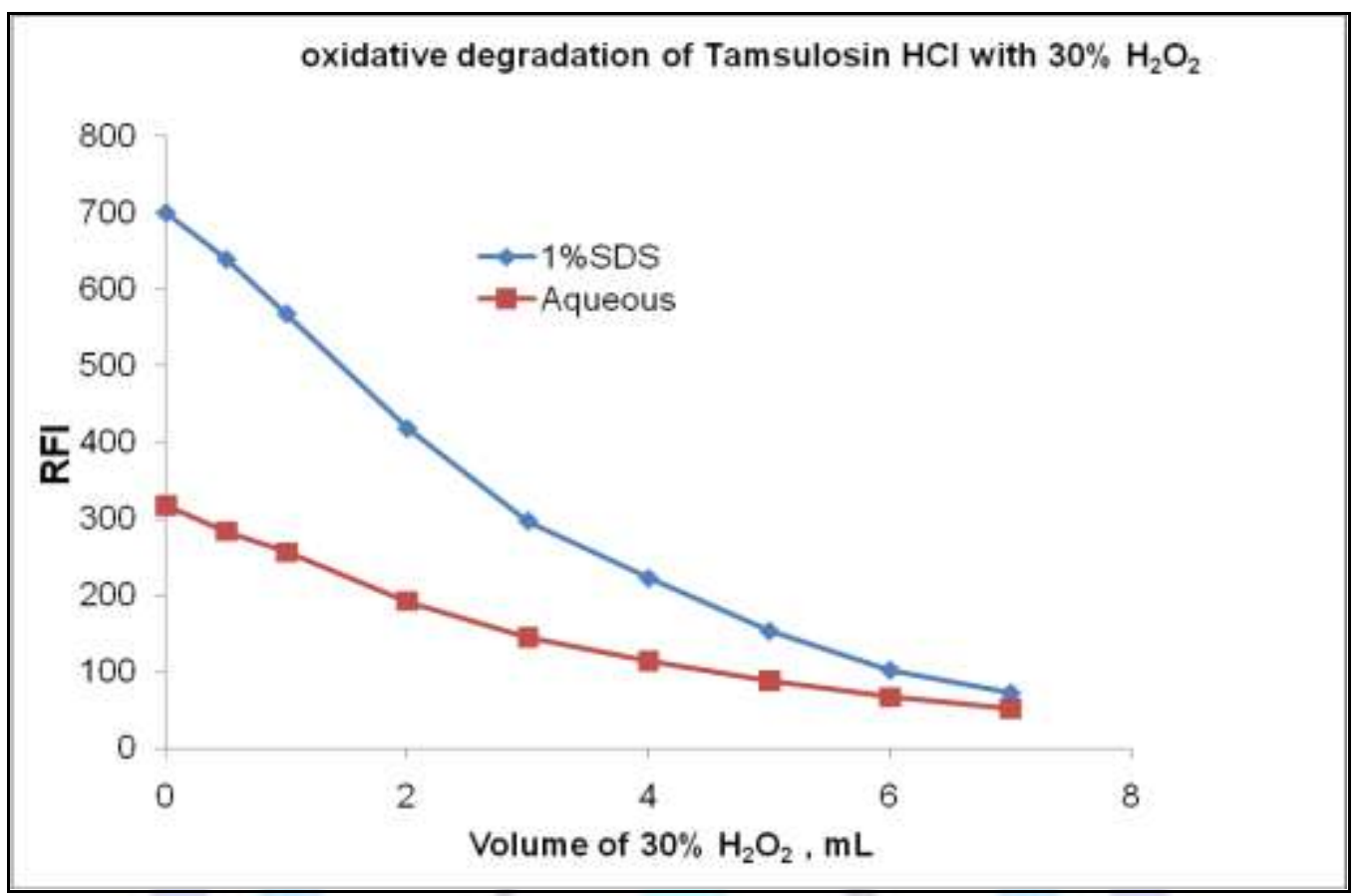

Fig. (10): Plot of relative fluorescence intensity of Tams. $\mathrm{HCl}\left(1.0 \mu \mathrm{g} \mathrm{ml}{ }^{-1}\right)$ versus volume of $30 \% \mathrm{H}_{2} \mathrm{O}_{2}$ in presence of : a Aqueous and $\$ 1 \%$ SDS media.

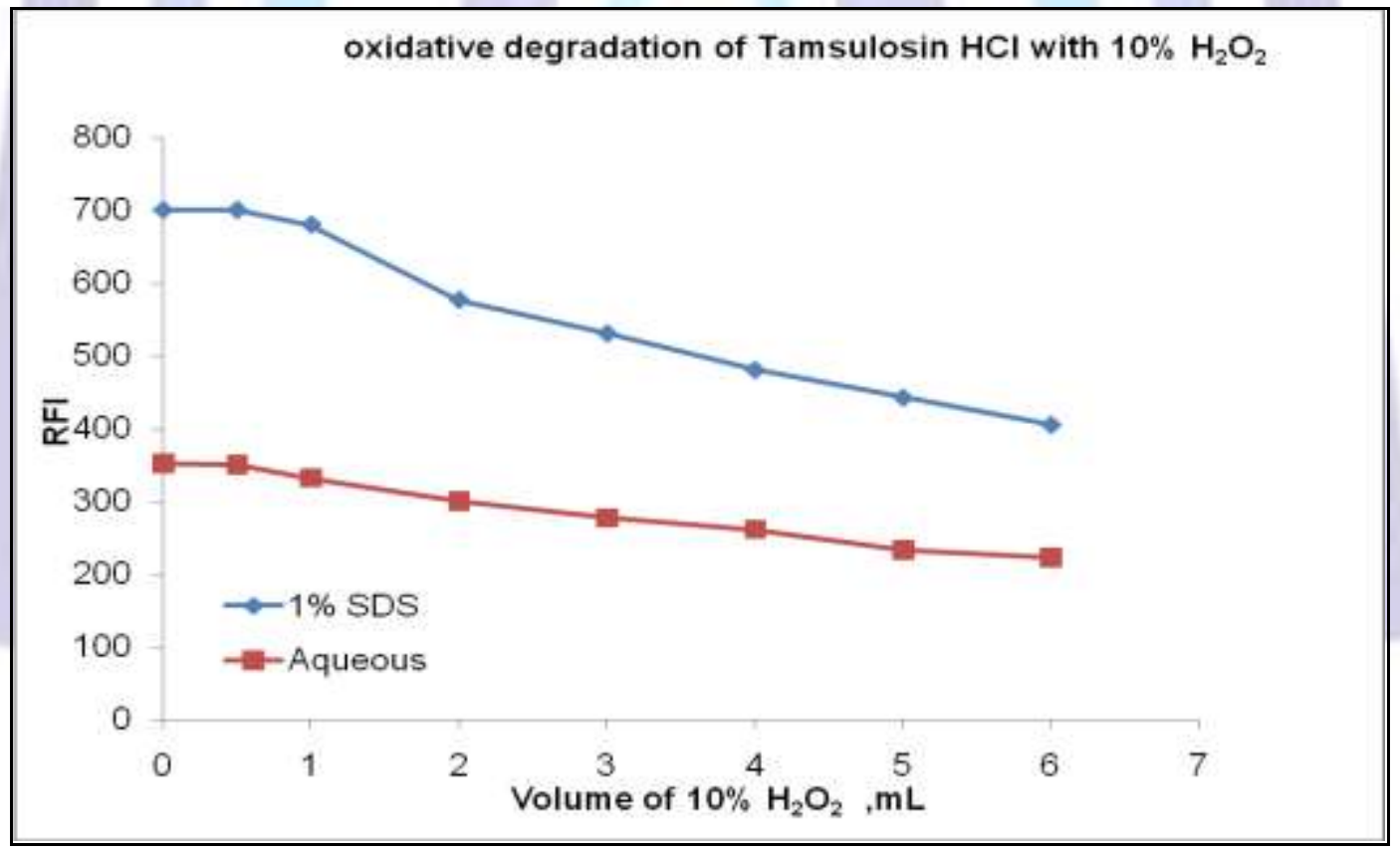

Fig.(11) :Plot of relative fluorescence intensity of Tams. $\mathrm{HCl}\left(1.0 \mu \mathrm{g} \mathrm{ml}^{-1}\right)$ versus volume of $10 \% \mathrm{H}_{2} \mathrm{O}_{2}$ in presence of : - Aqueous and $\downarrow 1 \%$ SDS media. 
Table (1) : Calibration data and Performance data of the proposed method for determination of Tams. $\mathrm{HCl}$ in pure form.

\begin{tabular}{|c|c|c|}
\hline Parameter & $\begin{array}{c}\text { Concentration } \\
\mu_{\mathrm{g} \mathrm{ml}}^{-1}\end{array}$ & RFI at $328 \mathrm{~nm}$ \\
\hline & 0.1 & 80 \\
\hline & 0.2 & 154 \\
\hline & 0.4 & 335 \\
\hline & 0.6 & 502 \\
\hline & 0.8 & 665 \\
\hline & 1.0 & 831 \\
\hline & 1.2 & 984 \\
\hline Concentration range $\left(\mu \mathrm{g} \mathrm{ml}^{-1}\right)$ & \multicolumn{2}{|c|}{$0.10-1.20 \mu \mathrm{g} \mathrm{ml}^{-1}$} \\
\hline Regression equation & \multicolumn{2}{|c|}{$\mathrm{RFI}=829.55 \mathrm{C}-2.150$} \\
\hline Correlation coefficient $(r)$ & \multicolumn{2}{|c|}{0.9998} \\
\hline Standard deviation of the residuals $\left(\mathrm{S}_{\mathrm{y} / \mathrm{x}}\right)$ & \multicolumn{2}{|c|}{7.557} \\
\hline$\%$ Recovery & \multicolumn{2}{|c|}{99.42} \\
\hline $\pm S D$ & \multicolumn{2}{|c|}{2.58} \\
\hline$\%$ RSD & \multicolumn{2}{|c|}{2.60} \\
\hline$\% \mathrm{Er}$ & \multicolumn{2}{|c|}{0.58} \\
\hline$(\mathrm{LOQ})$ & \multicolumn{2}{|c|}{$0.09 \mu \mathrm{g} \mathrm{ml}^{-1}$} \\
\hline (LOD) & \multicolumn{2}{|c|}{$0.03 \mu \mathrm{g} \mathrm{ml}^{-1}$} \\
\hline
\end{tabular}


Table (2) : Statistical analysis of the results of Tams. HCl in pure form by the proposed method, compared with Reference method [3].

\begin{tabular}{|c|c|c|c|c|}
\hline Parameter & \multicolumn{3}{|c|}{ proposed method } & Official method \\
\hline & $\mu \mathrm{g} \mathrm{ml}^{-1}$ taken & $\mu \mathrm{gll}^{-1}$ found & $\%$ Recovery & \% Recovery \\
\hline & 0.10 & 0.099 & 99.00 & \multirow{3}{*}{99.0} \\
\hline & 0.20 & 0.188 & 94.00 & \\
\hline & 0.40 & 0.406 & 101.50 & \\
\hline & 0.60 & 0.608 & 101.33 & \multirow[t]{2}{*}{100.7} \\
\hline & 0.80 & 0.805 & 100.63 & \\
\hline & 1.00 & 1.004 & 100.40 & 101.2 \\
\hline & 1.20 & 1.189 & 99.08 & 101.8 \\
\hline $\begin{array}{c}- \\
\text { Mean }(X)\end{array}$ & & 99.42 & & 100.68 \\
\hline \pm SD & & 2.58 & & 1.20 \\
\hline $\begin{array}{l}\text { No of } \\
\text { experiments }\end{array}$ & & & & 4 \\
\hline Variance & & 6.656 & & 1.44 \\
\hline$F$-test & & 4.62 & $(14,73)^{*}$ & \\
\hline Students $t$-test & & 0.906 & $(2.26)^{*}$ & \\
\hline
\end{tabular}

N.B. Figures between parentheses are the tabulated $F$ and $t$ values respectively at $\mathrm{P}=0.05^{[35]}$. 
Table (3):Accuracy and Precision data of the proposed method for the determination of Tams.HCl in pure and dosage forms ( Tamsulin capsule).

\begin{tabular}{|c|c|c|c|c|c|c|}
\hline \multirow{2}{*}{$\begin{array}{c}\text { Parameter } \\
\begin{array}{c}\text { Concentration } \\
\text { pg mL }\end{array}\end{array}$} & \multicolumn{3}{|c|}{$\begin{array}{l}\text { Intra-day precision } \\
\text { (Repeatability) }\end{array}$} & \multicolumn{3}{|c|}{$\begin{array}{l}\text { Inter-day precision } \\
\text { (intermediate precision) }\end{array}$} \\
\hline & 0.40 & 0.60 & 0.80 & 0.40 & 0.60 & 0.80 \\
\hline \multirow{3}{*}{$\begin{array}{l}\text { \%Recovery } \\
\text { Of pure Tams }\end{array}$} & 101.50 & 101.33 & 100.63 & 102.75 & 99.17 & 100.75 \\
\hline & 100.00 & 102.08 & 100.85 & 101.50 & 100.20 & 101.30 \\
\hline & 101.00 & 99.70 & 98.25 & 99.25 & 97.80 & 101.13 \\
\hline Mean (X) & 100.83 & 101.04 & 99.91 & 101.17 & 99.06 & 101.06 \\
\hline \pm SD & 0.76 & 1.20 & 1.44 & 1.77 & 1.20 & 0.28 \\
\hline \%RSD & 0.75 & 1.19 & 1.44 & 1.75 & 1.21 & 0.28 \\
\hline$\% E r$ & 0.83 & 1.04 & 0.09 & 1.17 & 0.94 & 1.06 \\
\hline \multirow{3}{*}{$\begin{array}{l}\text { \%Recovery } \\
\text { Tamsulin } \\
\text { capsule }\end{array}$} & 101.38 & 99.5 & 99.88 & 102.50 & 100.00 & 102.00 \\
\hline & 99.01 & 102.83 & 100.63 & 102.00 & 102.20 & 102.50 \\
\hline & 101.8 & 102.17 & 100.38 & 99.80 & 101.8 & 99.00 \\
\hline $\operatorname{Mean}(\bar{X})$ & 100.73 & 101.50 & 100.30 & 101.43 & 101.33 & 101.17 \\
\hline$\pm \mathrm{SD}$ & 1.50 & 1.76 & 0.38 & 1.44 & 1.17 & 1.89 \\
\hline \%RSD & 1.49 & 1.73 & 0.38 & 1.42 & 1.15 & 1.87 \\
\hline \%Er & 0.73 & 1.50 & 0.30 & 1.43 & 1.33 & 1.17 \\
\hline
\end{tabular}


Table (4): Application of the proposed method for the analysis of Tams.HCl in dosage form (Tamsulin capsule):

\begin{tabular}{|c|c|c|c|c|}
\hline Parameter & \multicolumn{3}{|c|}{ proposed method } & Official method \\
\hline $\begin{array}{c}\text { Concentration } \\
\text { taken } \\
\left(\mu \mathrm{g} \mathrm{mL}^{-1}\right)\end{array}$ & 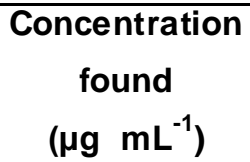 & \% Recovery & $\begin{array}{c}\overline{-} \\
\text { Mean }(\mathrm{X})\end{array}$ & \% Recovery \\
\hline \multirow{3}{*}{0.40} & 0.405 & 101.38 & \multirow{3}{*}{100.73} & \multirow{3}{*}{99.60} \\
\hline & 0.396 & 99.01 & & \\
\hline & 0.407 & 101.80 & & \\
\hline \multirow{3}{*}{0.60} & 0.597 & 99.50 & \multirow{3}{*}{101.50} & \multirow{3}{*}{101.4} \\
\hline & 0.617 & 102.83 & & \\
\hline & 0.613 & 102.17 & & \\
\hline \multirow[b]{3}{*}{0.80} & 0.799 & 99.88 & \multirow{3}{*}{100.30} & \multirow{3}{*}{101.9} \\
\hline & 0.805 & 100.63 & & \\
\hline & 0.803 & 100.38 & & \\
\hline \multirow{3}{*}{1.00} & 0988 & 0 & \multirow{3}{*}{100.13} & \multirow{3}{*}{100.7} \\
\hline & 1.005 & 100.50 & & \\
\hline & 1.011 & 101.10 & & \\
\hline Mean $(\bar{X})$ & & 100.67 & & 100.90 \\
\hline $\begin{array}{l}\text { Nominal content } \\
\text { of tamsulin } \\
\text { capsule }(\mathrm{mg})\end{array}$ & & 0.403 & & 0.404 \\
\hline \pm SD & & 0.611 & & 0.997 \\
\hline \%RSD & & 0.807 & & 0.988 \\
\hline$\%$ ER & & 067 & & 0.90 \\
\hline $\begin{array}{c}\text { No of } \\
\text { experiments }\end{array}$ & & 4 & & 4 \\
\hline Variance & & 0.37 & & 0.994 \\
\hline$F$ - test & & 2.69 & $44)^{*}$ & \\
\hline Student $s t$-test & & 0.4 & & \\
\hline
\end{tabular}

N.B. Figures between parentheses are the tabulated $\mathrm{F}$ and $\mathrm{t}$ values respectively at $P=0.05^{[35]}$. 
Table (5): Application of the proposed method for the analysis of Tams. $\mathrm{HCl}$ in dosage form (Tamic capsule):

\begin{tabular}{|c|c|c|c|c|}
\hline Parameter & \multicolumn{3}{|c|}{ proposed method } & Official method \\
\hline $\begin{array}{c}\text { Concentration } \\
\text { taken } \\
\left(\mu \mathrm{g} \mathrm{mL}^{-1}\right)\end{array}$ & 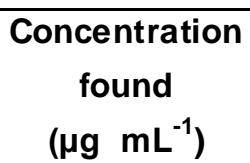 & $\%$ Recovery & $\operatorname{Mean} \overline{(X)}$ & \% Recovery \\
\hline \multirow{3}{*}{0.20} & 0.201 & 100.50 & \multirow{3}{*}{100} & \multirow{3}{*}{99.65} \\
\hline & 0.198 & 98.00 & & \\
\hline & $0 . .203$ & 101.50 & & \\
\hline \multirow{3}{*}{0.40} & 0.409 & 102.25 & \multirow{3}{*}{101.33} & \multirow{3}{*}{98.70} \\
\hline & 0.405 & 101.25 & & \\
\hline & 0.402 & 100.50 & & \\
\hline \multirow{3}{*}{0.60} & 0.611 & 101.83 & \multirow{3}{*}{101.50} & \multirow{3}{*}{98.10} \\
\hline & 0.603 & 100.50 & & \\
\hline & $0 . .613$ & 102.17 & & \\
\hline \multirow{3}{*}{0.8} & 0.790 & 98.75 & \multirow{3}{*}{98.79} & \multirow{3}{*}{98.90} \\
\hline & 0.797 & 99.63 & & \\
\hline & 0.784 & 98.00 & & \\
\hline Mean $(\bar{X})$ & & 100.41 & & 98.84 \\
\hline $\begin{array}{c}\text { Nominal content } \\
\text { of tamic capsule } \\
(\mathrm{mg})\end{array}$ & & 0.402 & & $0 . .395$ \\
\hline \pm SD & & 1.27 & & 0.64 \\
\hline \%RSD & & 26 & & 0.65 \\
\hline$\%$ ER & & & & 1.16 \\
\hline $\begin{array}{c}\text { No of } \\
\text { experiments }\end{array}$ & & 4 & & 4 \\
\hline Variance & & 1.61 & & 0.41 \\
\hline$F$ - test & & 3.93 & $44)^{*}$ & \\
\hline Student's $t$-test & & 2.21 & $15)^{*}$ & \\
\hline
\end{tabular}

N.B. Figures between parentheses are the tabulated $F$ and $t$ values respectively at $P=0.05^{[35]}$. 
Table (6): Application of the proposed method for the analysis of Tams. $\mathrm{HCl}$ in spiked human plasma:

\begin{tabular}{|c|c|c|}
\hline $\begin{array}{c}\text { Concentration } \\
\text { added } \\
\left(\mu \mathrm{g} \mathrm{ml}^{-1}\right)\end{array}$ & $\begin{array}{l}\text { Concentration } \\
\text { found } \\
\left(\mu \mathrm{g} \mathrm{ml}^{-1}\right)\end{array}$ & $\%$ Recovery \\
\hline \multirow{5}{*}{0.4} & 0.418 & 104.50 \\
\hline & 0.430 & 107.50 \\
\hline & 0.366 & 91.50 \\
\hline & 0.375 & 93.75 \\
\hline & 0.387 & 96.75 \\
\hline \multirow{5}{*}{0.8} & 0.777 & 97.13 \\
\hline & 0.815 & 101.90 \\
\hline & 0.806 & 100.75 \\
\hline & 0.824 & 103.00 \\
\hline & 0.775 & 96.90 \\
\hline \multirow{5}{*}{0.8} & 0.844 & 105.4 \\
\hline & 0.828 & 103.50 \\
\hline & 0.813 & 101.63 \\
\hline & 0.724 & 90.50 \\
\hline & 0.784 & 98.00 \\
\hline $\begin{array}{c}- \\
\text { Mean }(\mathrm{X})\end{array}$ & \multicolumn{2}{|c|}{99.51} \\
\hline \pm SD & \multicolumn{2}{|c|}{5.1} \\
\hline \%RSD & \multicolumn{2}{|c|}{5.13} \\
\hline \% ER & \multicolumn{2}{|c|}{0.49} \\
\hline
\end{tabular}

Table (7): Determination of the molar absorbtivity of Tams. $\mathrm{HCl}$ in aqueous and micellar media:

\begin{tabular}{|c|c|c|c|c|c|}
\hline $\begin{array}{c}\text { Concentration } \\
\text { taken } \\
\left(\mu \mathrm{g} \mathrm{ml}^{-1}\right)\end{array}$ & $\begin{array}{c}\text { Absorbance } \\
\text { In aqueous } \\
\text { medium at 280 } \\
\mathrm{nm}\end{array}$ & $\varepsilon$ water & $\begin{array}{c}\text { Absorbance } \\
\text { In micellar } \\
\text { medium at 280 } \\
\mathrm{nm}\end{array}$ & $\varepsilon$ micellar & $\varepsilon$ micellar \\
\hline 12.5 & 0.120 & 4270 & 0.124 & 4412.8 & $\varepsilon$ water \\
\hline 25 & 0.240 & 4270 & 0.248 & 4412.8 & 1.03 \\
\hline
\end{tabular}


Table (8): Determination of the fluorescence quantum yield of Tams. $\mathrm{HCl}$ in aqueous and micellar media:

\begin{tabular}{|c|c|c|c|c|c|}
\hline $\begin{array}{l}\text { Concentration } \\
\text { Taken of (Q.S.) } \\
\left(\mu \mathrm{g} \mathrm{ml}^{-1}\right)\end{array}$ & $\begin{array}{c}\text { Absorbance } \\
\text { at } 280 \mathrm{~nm}\end{array}$ & $\begin{array}{c}\text { Integral } \\
\text { fluorescence } \\
\text { of (Q.S.) }\end{array}$ & $\begin{array}{l}\text { Concentration } \\
\text { Taken of } \\
\text { studied drug } \\
\left(\mu \mathrm{g} \mathrm{m}^{-1}\right)\end{array}$ & $\begin{array}{c}\text { Integral } \\
\text { fluorescence } \\
\text { of studied drug } \\
\text { In aqueous } \\
\text { medium }\end{array}$ & $\begin{array}{l}\text { Integral } \\
\text { fluorescence } \\
\text { of studied drug } \\
\text { In micellar } \\
\text { medium }\end{array}$ \\
\hline 5.0 & 0.01 & 14491 & 12.5 & 9072 & 16098 \\
\hline 10.0 & 0.02 & 29599 & 25 & 15871 & 26654 \\
\hline
\end{tabular}

N.B. Dilute solution of quinine sulfate dissolved in $0.05 \mathrm{M}$ sulfuric acid with fluorescence quantum yield of 0.55 was us ed as reference reagent ${ }^{[36]}$.

\section{References}

1- Anthony C Moffat, M David Osselton, Brian Widdop and Laurent Y Galichet, Clarke's Analysis of Drugs and Poisons in pharmaceutical, body fluids and postmortem material, Third Edition , Phamaceutical Press , Great Britain , (2002).

2- Sweetman S. C. Martindale : the complete drug reference, Thirty-third Edition, Pharmaceutical Press, Great Britain, (2002).

3- The United States Pharmacopeia ,XXVII , National Formulary XXII , Rockvill , USP Convension Inc, Maryland (2011).

4- Sibel AO, zkan a, Bengi Uslu a, Hassan Y, Aboul-Enein b., Voltammetric investigation of Tamsulosin.

Talanta ,61, 2003, 147-156.

5- Nilam A.Gadhave, Minal R. Ghante, Atul D. Nikam, Sanjay D. Sawant,

Simultaneous estimation of tamsulosin hydrochloride and finasteride in combined dosage form by UV spectroscopy method. Journal of Pharmacy Research,4(8), 2011, 2672-2674.

6- Qi M L, Wang P, Cong R H, Determination of the enantiomers of tamsulosin hydrochloride and its synthetic intermediates by chiral liquid chromatography. Chromatographia, 59(3-4) , 2004, 251-254.

7- Zhang ZF, Yang GL, Liang GJ , Liu HY, Chen Y, Chiral separation of tamsulosin is omers by HPLC using cellulose Tris (3,5-dimethylphenylcarbamate) as a chiral stationary phase. J.Pharm. Biomed.Anal., 34(3), 2004, 689-693.

8- Aboul-Enein HY, Hussein RF, Radwan MA, Yusuf A, Al-Ahmadi W, Al-Rawithi S, Tamsulosin dissolution from phamaceutical dosage forms using an automated HPLC system. J.Liq.Chromatogr.Relat.Technol., 26(7), 2003,11091116.

9- Nageswara Rao R, Kumar Talluri MVN, Narasa Raju A, Dhananjay D Shinde, Ramanjaneyulu GS, Development of a validated RP-LC/ESI-MS-MS method for separation, identification and detemination of related substances of tamsulosin in bulk drugs and formulations. J.Pharm.Biomed.Anal.,46, 2008, 94-103.

10- Macek J, Kl'ýma J, Ptcek P, Rapid determination of tamsulosin in human plasma by high-performance liquid chromatography using extraction with butyl acetate. J. Chromatogr. B., 809, 2004, 307-311.

11- Sangita Agarwal K, Veeran Gowda, Amlan Kanti Sarkar, Debotri Ghosh, Uttam Bhaumik, Tapas Kumar Chattaraj, Tapan Kumar Pal, Simultaneous Determination of Tamsulosin and Dutasteride in Human Plasma by LC-MS-MS. Chromatographia, 67, 2008, 893-903.

12- Pekka Keski-Rahkonen , Olavi P“arssinen , Esa Lepp“anen , Timo Mauriala ,Marko Lehtonen , Seppo Auriola, Determination of tamsulosin in human aqueous humor and serum by liquid chromatography-electrospray ionization tandem mass spectrometry. J.Pharm.Biomed.Anal., 43, 2007, 606-612.

13- Qi ML, Wang P, Liu LH, Determination of tamsulosin in dog plasma by liquid chromatography with atmospheric pressure chemical ionization tandem mass spectrometry. J.Chromatogr.B.Anal.Technol.Biomed.Life.Sci., 805(1), (2004), 7-11.

14- Ding L, Li LM, Tao P, Yang J, Zhang ZX, Quantitation of tamsulosin in human plasma by liquid chromatographyelectros pray ionization mass spectrometry .J.Chromatogr. B.Anal.Technol.Biomed.Life.Sci., 767(1), 2002, 75-81.

15- Matsushima H, Takanuki K, Kamimura H, Watanabe T, Higuchi S, Highly sensitive method for the detemination of tamsulosin hydrochloride in human plasma dialysate, plasma and urine by high-performance liquid chromatographyelectros pray tandem mass spectrometry J.Chromatogr.B.Biomed.Appl. 695(2), 1997, 317-327.

16- Andrea Kavalírová , Marie Pospišilová , Rolf Karlícjek , Enantiomeric purity determination of tamsulosin by capillary electrophoresis using cyclodextrins and a polyacrylamide-coated capillaryll Farmaco, 60, 2005, 834-839. 
17- Hertz P. M. R. and McGown L. B., Organized media for fluorescence analys is of complex samples: comparis on of bile salt and conventional detergent micelles in coal liquids. Anal.Chem., 64(23) ,1992, 2920.

18- Wehry E L, in Frank A.Settle, ed., Handbook of Instrumental Techniques for Analytical Chemistry.Chapter 26, Molecular Fluorescence and Phosphorescence Spectrometry. Prentice Hall,New Jersy. U.S.A.(1997).

19- Dorsey JG, Micellar liquid chromatography. Adv. Chromatogr. 27, (1987),198.

20-Alarfaj NA, Aly FA, Micelle-Enhanced Spectrofluorimetric Method for Determination of Cholesterol-Reducing Drug Ezetimibe in Dosage Forms. J. Fluoresc. 2011.

21-Walash Ml, Belal F, El-Enany N, Eid M, El-Shaheny RN, Stability-indicating micelle-enhanced spectrofluorimetric method for detemination of loratadine and desloratadine in dosage forms. Luminescence. 2011.

22-Culzoni MJ, Aucelio RQ, Escandar GM, Spectrofluorimetry in organized media coupled to second-order multivariate calibration for the determination of galantamine in the presence of uncalibrated interferences. Talanta., 82(1), 2010, 325-32.

23-Walash Ml, Belal F, El-Enany N, Abdelsalam A, Spectrofluorometric detemination of verapamil hydrochloride in pharmaceutical preparations and human plasma using organized media: application to stability studies. J. AOAC. Int,. 89(6), 2006, 1565-72.

24-Ocaña JA, Barragán FJ, Callejón M, Spectrofluorimetric and micelle-enhanced spectrofluorimetric detemination of gatifloxacin in human urine and serum. J. Pharm. Biomed. Anal., 37(2), 2005, 327-32.

25- Ocana JA, Barragan FJ, Callejon M, Fluorescence and terbium-sensitized luminescence detemination of garenoxacin in human urine and senum. Talanta., 63(3), 2004, 691-697.

26- Arancibia J A, Escandar G M, Detemination of naproxen in phamaceutical preparations by room-temperature phos phorescence. A comparative study of several organized media. Analyst., 126 (6), 2001, 917-22.

27- González JA, Callejón Mochón M, de la Rosa FJ, Spectrofluorimetric detemination of levofloxacin in tablets, human urine and serum. Talanta., 52(6), 2000, 1149-56.

28- Sbai M, Lyazidi SA, Lerner DA, del Castillo B, Martin MA, Use of micellar media for the fluorimetric detemination of ellipticine in aqueous solutions. J. Pharm. Biomed. Anal. ,14(8-10), 1996, 959-65.

29-_Sancenón J, de la Guardia M, Micellar enhanced fluorimetric determination of carbendazim in natural waters Anal. Chim. Acta., 287(1-2), 1994, 49-5.

30- Manuel V. Galdú, Miguel de la Guardia, Lorenzo Braco, Influence of anionic surfactants on the sensitisation of the fluorimetric determination of fenproporex Analyst.. 112, 1987, 1047-1050.

31- Perrin, D.D. and Dempsey B. Buffers for pH and Metal Ion Control. Chapman and Hall, London ; Wiley, New York. (1974), 153.

32- Hinze W L, Singh HN, Baba Y, Harvey NG, Micellar enhanced analytical fluorimetry. Trends. Anal. Chem. 3, 1984, 193-9.

33- Ohannesian L. Handbook of pharmaceutical analysis. Marcel Dekker: New York, Basel, 2002; electronic version.

34- ICH Ham onized Tripartite Guideline, Validation of analytical procedures: Text and methodology, Q2(R1), Current Step 4 Version, Parent Guid lines ON Methodology Dated November 6, 1996, Incorporated in November 2005. http://www.lch.org/LOB/media/MEDIA417.pdf.

35- Miller JC and Miller JN, Statistics and Chemometrics for Analytical Chemistry, Fifth Eidition . Prentice Hall, Harlow. England. (2005).

36- Tang B, Wang X, Jia B, Niu J, Ying Wei Y, Chen Z, Wang Y, Simple,rapid, and sensitive spectrofluorimetric determination of zaleplon in micellar medium. Anal. Lett. 36, (2003), 2985-97. 